\title{
Supply chain assessment of the organizational learning and market uncertainty on corporate performance of small scale steel industry in Indonesia
}

\author{
Prihatin Tiyanto Priagung Hutomo $^{\mathrm{a}^{*}}$ and Emiliana Sri Pudjiarti ${ }^{\mathrm{a}}$
}

${ }^{a}$ Universitas 17 Agustus 1945 Semarang, Indonesia

\author{
C H R O N I C L E \\ Article history: \\ Received October 2, 2020 \\ Received in revised format \\ November, 10, 2020 \\ Accepted December 112020 \\ Available online \\ December 112020 \\ Keywords: \\ Supply chain management \\ Effective organizational \\ learning \\ Human resource development \\ Market uncertainty \\ Corporate performance
}

\section{A B S T R A C T}

\begin{abstract}
The SMEs is currently experiencing many challenges, especially performance improvements. To improve performance, companies are required to increase the effective organizational learning so that it is emphasized on improving human resource development in addition to being able to overcome market uncertainty. This study examined empirically the variables of human resource development and market uncertainty by using the moderating variable of effective organizational learning to increase corporate performance. Using data from 100 SMEs in two regencies in Central Java, and carrying out using AMOS 22, the results prove that effective organizational learning moderates human resource development and market uncertainty in their activities. These results prove that human resource development is needed to improve the effective organizational learning. This study provides the best insight into human resource development, especially in the SMEs. Some of the observed causes have been discussed in this study.
\end{abstract}

(C) 2021 by the authors; license Growing Science, Canada.

\section{Introduction}

The role of effective organizational learning is vital for the progress of industry performance in the long run (ZgrzywaZiemak, 2015). Effective organizational learning is the key to the success of organizational performance when it is associated with the development of human resources, market uncertainty conditions even though they are interrelated (Kareem, 2019; Kipley et al., 2018). Organizational learning is a multidimensional and complex construct with various kinds of definitions covering a broad picture (Crossan et al., 1995; Tsang, 1997; Easterby-Smith, 1997). The terminology of organizational learning and organizational learning is often exchanged, but in the basic literature each of them is separated (Easterby-Smith, 1997; Sun, 2003). Literature in organizational learning emphasize understanding the learning process in organizing organizations with more empirical and theoretical approaches. In this view, the contextual factors, for example organizational size, age, industry, form of ownership, type of activity, national culture or environmental availability, as the basis are seen as the difference in relations between organizational learning and various types of functions under different conditions and organizational performance. Organizational effectiveness is largely a critical variable in organizational analysis and because almost most organizational theories want effectiveness (Cameron, 1980; Goodman et al., 1977). Georgopoulus and Tannenbauk (1957) define organizational effectiveness as the extent to which an organization as a social system, provides certain resources and facilities, fulfills its objectives without weakening the means and resources and without undue obstacles to its members. Roy and Dugal (2005) argue that, organizational effectiveness is the net satisfaction of all constituents in the process of collecting and transferring inputs into output efficiently. Organizational theorists postulate five approaches to measuring organizational effectiveness such as approaches to achieving goals (Etzioni, 1960; Pfeffer, 1977), systems resource approaches (Wolfe \& Putler, 2002), internal process approaches (Papadimitriou \& Taylor, 2000; Sowa et al., 2004), strategic constituency approaches (Connolly et al., 1980; Trieschmann et al., 2000) and competing value approaches (Price, 1968; Quinn and Rohrbaugh, 1981).

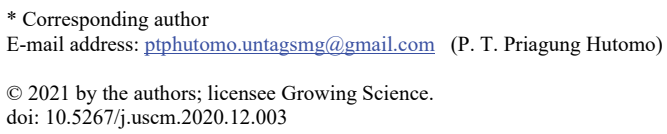


Argyris and Schon (1996) propose a model that facilitates organizational learning, namely, how organizations learn and adapt to uncertain contexts. This is important because organizational learning can support change and in particular referring to as a strategic change involves efforts to change the modes of cognition and current actions to enable organizations to take advantage of important opportunities or to overcome the consequences of environmental threats (Gioia and Chittipeddi, 1991, p. 433). The term organizational learning is sometimes used to indicate a product, and in other cases to show a process. Learning objectives are the tendency of organizations to behave in participatory methods for the use of learning opportunities. The purpose of learning is to determine the extent to which an organization can learn (Huang, 2010). Thus, organizational learning can be seen as a proactive response to the need to adjust to the greater uncertainty presented by increasing levels of uncertainty and responsible for changing strategic directions to occupy more competitive positions (Pavitt, 1991; Dodgson, 1991). The objective approach model defines effectiveness as the extent to which an organization has achieved its objectives (Price, 1968). The goal approach is most widely used, and assesses organizational effectiveness in terms of its success in realizing its objectives (Weese, 1997). Yuchtman and Seashore (1967) proposed a system of resource models, defining effectiveness as the ability of an organization, either in absolute or relative terms, to exploit its environment in the acquisition of scarce and valued resources. The emphasis on human resources leads to a framework, where identifying key stakeholder views of effectiveness is considered very important (Connolly et al., 1980). The approach to competing values and their effectiveness criteria arises from the assessment of organizational effectiveness in profit organizations. The most rigorous and influential multidimensional approach builds on five organizational effectiveness frameworks, namely the value value competition approach (Quinn \& Rohrbaugh (1981; 1983). Effective organizational learning provides a moderating influence on human resource development (Kareem, 2019) and on market uncertainty (Kipley et al., 2018; Pudjiarti \& Hutomo, 2020). In its practice human resource, management can improve organizational performance (Hutomo \& Pudjiarti, 2018), although it has been done a lot, empirical studies are still limited. The results of this study intend to deepen the insight that the effective organizational learning can improve company performance.

\section{Literature Review and Hypotheses}

\subsection{Human resource development and the effective organizational learning}

The general consensus in the literature of organizational learning is that learning at the organizational level is a prerequisite for change and the success of organizational performance (Garvin, 1993; Hendry, 1996). According to Watkins and Marsick (1996) learning can improve employees' intellectual abilities; because the organization will ultimately be better by having educated employees. Organizational learning can be regarded as a dynamic process of creation, acquisition and integration of knowledge aimed at developing resources and capabilities that contribute to better performance (Chonko et al., 2003; Choe, 2004; Gonzales, 2001; Lopez et al., 2005; Wu \& Cavusgil, 2006). Some researchers and scholars of human resource development try to examine and highlight the relationship between human resource development and organizational performance and effectiveness. Otoo and Mishra (2018) explore the effect of the practice of human resource development on organizational effectiveness by considering the competency role of employees and found that HRD practices had an impact on employee competencies in improving organizational effectiveness. Examines the impact of human resource development interventions on organizational effectiveness through employee competencies. Shoo stated that HRD interventions have a significant impact on developing employee competencies that positively increases organizational effectiveness. Alagaraja, Cumberland, and Choi (2015) investigated the effects of the contribution of human resource development on organizational performance. Both types of HRD contributions to strategic value and transaction effectiveness significantly improve organizational performance (Mufti et al., 2019). Alagaraja (2014) states that HRD and HRM have important contributions to the development, advancement of knowledge, and application of theories in improving HR service delivery and its impact on organizational performance. Alagaraja (2013) argues that the significance and strength of human resource development is based on its ability to engage and respond to stakeholder expectations and involvement in organizational change efforts. Nilsson and Ellstrom (2012) state that the strategy of developing human resources in an organization plays a key role in increasing employee competencies that contribute, in aggregate to organizational performance. HRD research has conceptualized and empirically developed positive relationships between variables or one of the indicators or interrelated interrelations between HRD practices and organizational effectiveness (Colbert et al., 2014; Jiang and Liu, 2015), employee involvement (Rior \& et al., 2005), employee communication (Chen, 2008), personality (Colbert et al., 2014), knowledge management process (Rahman et al., 2013). Nilsson and Ellstrom (2012) emphasize that developing a strategy for developing human resources in an organization is an opportunity for employees to enrich the competencies of those who contribute, in aggregate for company performance.

\section{$\mathrm{H}_{1}$ : Development of human resources has a positive effect on the effective organizational learning.}

\subsection{Market uncertainty and the effective organizational learning}

Market uncertainty conditions is a separate, prominent and unpredictable event (Pudjiarti \& Hutomo, 2020). Uncertainty can also be caused by the way market participants relate to one another, for example, in terms of opportunistic behavior (Sutcliffe \& Zaheer, 1998). The various needs of market participants and how these actors interact in the supply chain management perspective, depending on each other can also cause uncertain conditions. Business companies usually get 
valuable information and other resources through interaction with various types of market players in supply chain management such as customers, suppliers and consultants, external interactions can also be problematic issues. For example, companies and time management and cognitive capacity are limited, which implies that they have the resources to interact with a number of actors at a certain point in time to enhance the performance of supply chain management. Thus, companies make choices, either consciously or unconsciously, to interact with several partners while excluding others (Gulati et al., 1999). Due to lack of information, it may be difficult to solve a very significant environmental actor or sector. In addition, in a supply chain management perspective, choosing who interacts, and may not always be a deliberate choice, because market participants pursue their own needs and goals when people start interacting, not company focus. For example, customers and market participants often express their diverse needs, demands and opinions. Over time, customers and suppliers play an active role in supply chain management in designing and modifying products and services, sometimes insofar as they are responsible for the process (Pudjiarti \& Hutomo, 2020). Such initiatives may be more or less unexpected and come and go according to the changing needs of these actors. This raises uncertainty in terms of initiative, often time consuming, more or less unexpected from a variety of different market participants. Another uncertainty, which can affect the activities and focus of the company, is uncertainty which "arises from a lack of knowledge about natural conditions" which produces unexpected results (Sutcliffe and Zaheer, 1998, p. 6), e.g in the case of unpredictable variations in the supply of vital input factors. This represents certain types of environmental uncertainty in supply chain management that must be handled in an adequate manner because companies need regular supplies to operate effectively (Katz and Kahn, 1978).

\section{$\mathrm{H}_{2}$ : Market uncertainty has a positive effect on companies to create the effective organizational learning.}

\subsection{Human Resource Development and Company Performance}

The emphasis on human resources in organizations reflects the view that market value is less dependent on tangible resources, but rather on intangible resources, especially human human resources (Stiles \& Kulvisaechana, 2005). Recruiting and retaining employees is best part of the human resource development framework. Organizations must also improve the skills and abilities of employees by encouraging individuals to learn and create a supportive environment where knowledge can be created, shared and applied to achieve the company's goals of the organization. Increased employee skills and abilities are expected to create future returns through increased productivity and business performance (Shih et al., 2006). Lee and Bruvold (2003) state that comprehensive training activities are positively related to productivity; reduce staff's intention to go and organizational effectiveness. Raghuram (1994) argues that staff and training lie in processes that aim to develop the skills needed to maintain competitive advantage and organizational performance. Individual and team training and development can be used to add new skills to the resources and capabilities of existing employees.

\section{$\mathrm{H}_{3}$ : Development of Human Resources has a positive effect on Company Performance.}

In this study, market uncertainty was conceptualized to measure the level of change in customer composition and their preferences (Jaworski \& Kohli, 1993, Slater \& Narver, 1994). In this definition, market uncertainty also tries to capture the dynamics in the customer base, the needs and market uncertainty in the level of change in the company's competitors (Santos-Vijande \& Alvarez-Gonzalez, 2007). Market uncertainty is a prediction of the future of market preferences, competitive conditions and the evolution of environmental forces (Milliken, 1987). In this case, the concept of market uncertainty tries to simultaneously assess the changes faced by companies in the composition of their customers and competitors (market dynamics), and the struggle to prepare organizations to face new competitive situations (market uncertainty) (Santos-Vijande \& Alvarez-Gonzalez, 2007). The term innovation was formulated by Afuah (1998) and Garcia and Calantone (2002) as inventions for commercialization. In the strategic management literature innovation is very important for companies to create value and maintain competitive advantage in an already complex and rapidly changing environment (Madhavan \& Grover, 1998; Subramaniam \& Youndt, 2005). Innovation performance can be defined as the sum of company innovations (Salomo, Strecker \& Talke, 2007). Other definitions require the company's activities in utilizing its competencies to become new products and services. Innovation performance can be divided into two categories; incremental (derivative) or radical (breakthrough). Additional innovation performance requires improving and strengthening existing organizational products, processes, technologies and structures (Chandy \& Tellis, 1998; Dosi, 1988; OECD, 2005). Conversely, the performance of radical innovation is one that produces fundamental changes in the product, process, technology, structure and methods of the company (Dewar \& Dutton, 1986; Meyers \& Tucker, 1989; OECD, 2005; Song \& Montoya-Weiss, 1998). To survive, companies need innovation performance, where they need to balance the performance of innovations both radically and gradually (Farjoun, 2010; He \& Wong, 2004; March, 1991; Probst \& Raisch, 2005). Innovation performance has a number of ways that can be measured. This can be measured in terms of innovative inputs such as R \& D expenditure, or innovation output such as patent frequency (Griliches, 1984; Henderson \& Cockburn, 1996). Coorper and Kleinschmidt (1995) present a large number of collective steps for innovation performance: profit impact, relative profitability to competitors, success rate, sales percentage, sales impact, relative profitability to expenditure, ranking of technical success, success in meeting sales goals and overall success. More innovative companies will be more successful in adapting to changing environments that allow them to do better. The ability to monitor and adapt to environmental trends determines the survival of a company (Keats \& Hitt, 1988). When a company is faced with substantial market uncertainty and other types of environmental disturbances, innovation is considered very important (Hult et al., 
2004). In a dynamic environment, product preferences always change. Companies must be aware of this and can adapt to the situation. In addition, under uncertain market conditions, identification of changing customer needs and the evolution of environmental forces is more difficult (Santos-Vijande \& Alvarez-Gonzalez, 2007). This increases the likelihood that the company's products and services will not suit the needs and preferences of the customer for a certain period of time. To avoid this situation, companies can try to have proactive behavior that tries to anticipate and direct new demands (Miles $\&$ Snow, 1978). However, if this fails, the company's innovation performance will decrease, so that no competitive advantage will be obtained. March (1991) also states that high market uncertainty can increase investment uncertainty and investment risk and, as a consequence, reduce the company's innovation activities. Therefore, if the company is faced with high market uncertainty, the success of the company's activities to improve its competence into new products and new services will be negatively affected.

\section{$\mathrm{H}_{4}$ : Market uncertainty has a positive effect on changes in market preferences to improve organizational performance.}

\subsection{Effective organizational learning and the performance of the Company}

The general consensus in the learning organization literature that learning at the organizational level is a prerequisite for successful organizational change and performance (Garvin, 1993; Hendry, 1996). According to Watkins and Marsick (1996) learning can improve employees' intellectual abilities; because such an organization will ultimately be better by having educated employees. Organizational learning can be regarded as a dynamic process of creation, acquisition and integration of knowledge aimed at developing resources and capabilities that contribute to better performance (Chonko et al., 2003; Choe, 2004; Gonzales, 2001; Lopez et al., 2005; Wu and Cavusgil, 2006). Garver (1996) shows that there is a significant positive relationship between the size of learning activities and workplace performance which shows higher performance involved in a larger volume of learning activities. Jashapara (1993) reports that learning in an organization has a positive impact on organizational performance. Skerlavaj, Stemberger, Skrinjar and Dimovski (2006) report from their research that organizational learning has a positive direct impact on performance. The findings made by Spicer and Sadler-Smith (2006) in small manufacturing companies also show that organizational learning has a positive relationship with the company's financial and non-financial performance. Similarly, many other empirical studies show a positive relationship between organizational learning and performance outcomes (Correa, Morales, and Pozo (2007) Ellinger et al., 2003; Jimenez and Navarro (2006) Khandekar and Sharma (2006) Power and Waddell (2004) Schroeder, Bates, and Junttila, 2002).

\section{H5: Effective organizational learning positively influences company performance.}

\section{Research Framework}

In an integrated manner, it can be hypothesized that effective organizational learning (Effective Organization Learning = EOL) has a positive moderating effect between human resources development (HRD) and volatile markets (Market Uncertainty $=\mathrm{MT})$ on improving company performance $($ Corporate Performace $=\mathrm{CP})($ Fig. 1).

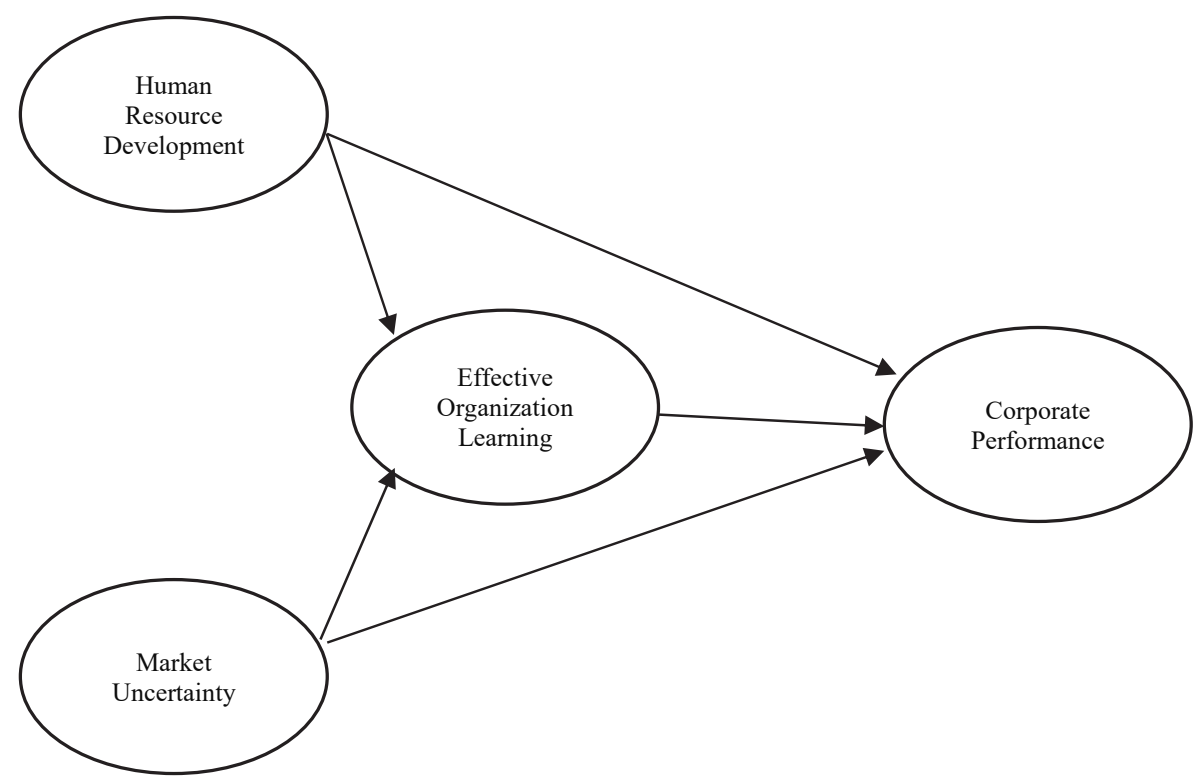

Fig. 1. Research Framework 


\section{Methodology}

This study was to determine the moderating effect the effective organizational learning between the development of human resources and a volatile market to improve the performance of companies in the SMEs in Tegal, Central Java. The questionnaires distributed amounted to 100 respondents, consisting of 50 SMEs in Tegal Regency and 50 SMEs in Tegal City. Before the questionnaire analysis was tested with validity and reliability tests as many as 30 respondents. Of the thirty respondents tested there were no identifiable problems. A total of 100 respondents were given questionnaires and asked about the things contained in the questionnaire through face to face. Respondents The majority of entrepreneurs/owners and $95 \%$ are male and 5\% are women. As much as $46 \%$ aged 41 to 45 years and $24 \%$ aged 46 to 50 years, while $15 \%$ were aged 31 to 35 years, $12 \%$ aged 36 to 40 years, the remaining $3 \%$ are over 50 years old. The respondent characteristics shows that 96 are owners and 4 are staff members with mostly having more than 6 years of working experience. After all data are analyzed, and tabulated, then inputed into SPSS and AMOS 22. The answers to questions from each variable are measured by the Likert scale from 1 (strongly disagree) to scale 7 (strongly agree). The variable of HRD variable was measured with indicators, X11: training; X12: employee participation in decision making; X13: individual improvement efforts; X14: maintain the best employees. The variable of market uncertainty was measured with indicators, X21: consumer preferences are changing rapidly; X22: very broad needs; X23: high turnover of buyers; X24: pressure on new product offerings. The variable of effective organizatoional learning was measured with indicator, $z 1$ : cannot be replicated; $z 2$ : rare; $z 3$ : value is more than competitors, and $\mathrm{z} 4$ : not easily replaced. Lastly, the variable of company performance was measured with the indicators of Y2: new product; Y3: growth; Y4: productivity.

\section{Results}

To reinforce and clarify the results of the Full Model SEM, it can be seen in the final stage of the SEM Suitability Index, which shows the definite value and the calculation value of AMOS 22 results, as seen in Table 1.

Table 1

Final Stage SEM Conformity Index

\begin{tabular}{lccc}
\hline \multicolumn{1}{c}{ Criteria } & Cut off value & Results & Note \\
\hline Chi- Square & small & 117,182 & Fit \\
Significance Probability & $\geq 0.05$ & 0.091 & Fit \\
RMSEA & $\leq 0.08$ & 0.032 & Fit \\
GFI & $\geq 0.90$ & 0.930 & Fit \\
AGFI & $\geq 0.90$ & 0.902 & Fit \\
CMIN/DF & $\leq 2.00$ & 1.196 & Fit \\
TLI & $\geq 0.95$ & 0.977 & Fit \\
CFI & $\geq 0.95$ & 0.981 & Fit \\
\hline
\end{tabular}

Hypothesis testing can be accepted or rejected by comparing the probability value (p) with the alpha $(\alpha)$ value determined at 0.05 . The probability value (p) is smaller than the value of $\alpha(0.05)$, so the hypothesis can be accepted. Vice versa, if the probability value $(\mathrm{p})$ is greater than the value of $\alpha(0.05)$, then the hypothesis is rejected. The final results can be seen in Table 1. Since HRD has a positive effect with $\mathrm{p}=0.008<\mathrm{of} \alpha=0.05$, the hypothesis is accepted. Similarly, market uncertainty has a positive effect with $\mathrm{p}=0.012<\mathrm{of} \alpha=0.05$, and this proved that the hypothesis is accepted. The moderation requirement is that if both positively influence, then both of them are tested further. In this study the effective organizational learning is a prerequisite for moderation.

Table 2

Hypothesis Testing

\begin{tabular}{ccccccc}
\hline Variable & & & Coefficient value & CR & Probability & Confirmation \\
\hline EOL & $\leftarrow$ & HRD & 0.107 & 2.647 & 0.008 & Significant \\
EOL & $\leftarrow$ & MU & 0.112 & 2.525 & 0.012 & Significant \\
CP & $\leftarrow$ & EOL & 0.096 & 2.570 & 0.010 & Significant \\
CP & $\leftarrow$ & HRD & 0.111 & 2.404 & 0.016 & Significant \\
CP & $\leftarrow$ & MU & 0.116 & 2.273 & 0.023 & Significant \\
\hline
\end{tabular}

Note: $\mathrm{EOL}=$ Effective Organization Learning; $\mathrm{HRD}=$ human resources development; $\mathrm{MU}=$ Market Uncertainty; $\mathrm{CP}=$ company performance

Statistical testing of the effect of HRD on EOL reveals a coefficient of 0.107 and Critical Ratio (C.R) 2.647. This means that HRD has a significant positive effect on EOL. According to Otoo and Mishra (2018) the practice of developing human resources increases organizational effectiveness by considering the competency role of employees. Next, states that HRD interventions have a significant positive impact on developing employee competencies in increasing organizational effectiveness. HRD empirically builds positive relationships between each indicator or the unity of HRD practices and organizational effectiveness (Colbert et al., 2014; Jiang \& Liu, 2015). Moreover, the examination of the effect of market 
uncertainty on EOL produces a coefficient value of 0.112 and a C.R of 2.525. It means that market uncertainty has a significant positive effect on EOL. This is in accordance with Argyris and Schon's (1996) study examining how organizations learn and adapt to uncertain contexts. This is in the opinion of that organizational learning can be seen as a proactive response to the need to adjust to greater uncertainty presented by increasing levels of uncertainty and responsible for changing strategic directions to occupy more competitive positions. The testing of HRD on CP shows a coefficient of 0.111 and C.R 2.404. It means that HRD has a positive and significant effect on CP. This finding shows that the increased skills and abilities of employees can create future returns through increased productivity and business performance (Shih, Chiang, \& Hsu, 2006). This is also supported by the findings of Raghuram (1994) that staff and training lie in processes that aim to develop the skills needed to maintain competitive advantage and organizational performance. Individual and team training and development can be used to add new skills to the resources and capabilities of existing employees.

The statistical testing of market uncertainty on CP produces a coefficient value of 0.116 and C.R 2.273, meaning that market uncertainty has a positive effect on CP. This supports the findings from Keats and Hitt (1988) explaining that the ability to monitor and adapt to environmental trends determines the survival of a company. When a company is faced with substantial market uncertainty and other types of environmental disturbances, innovation is considered very important (Hult et al., 2004). In a dynamic environment, product preferences always change. Companies must be aware of this and can adapt to the situation. To avoid this situation, companies can try to have proactive behavior that tries to anticipate and direct new demands (Miles \& Snow, 1978). However, if this fails, the company's innovation performance will decrease, so that no competitive advantage will be obtained. March (1991) also states that high market uncertainty can increase investment uncertainty and investment risk and, as a consequence, reduce the company's innovation activities. Therefore, if the company is faced with high market uncertainty, the success of the company's activities to improve its competence into new products and new services will be negatively affected. This is also indicated by the results of the coefficient -0.21 where market uncertainty against $\mathrm{CP}$ has a negative coefficient (Fig. 2).

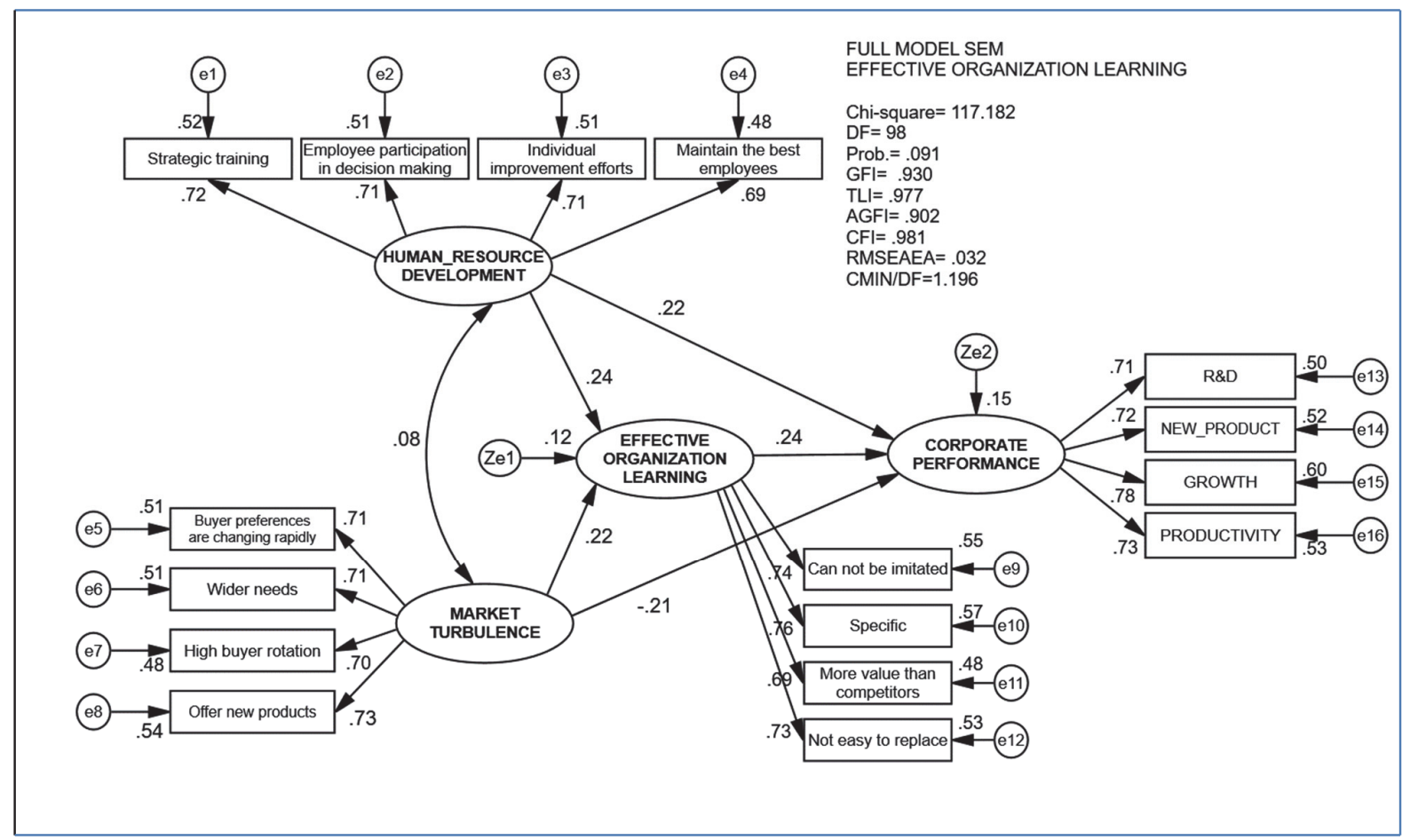

Fig. 2. Measurement Results of HRD, MT, EOL and CP variables

The hypothesis examination of the EOL effect on CP produces a coefficient of 0.096 and a C.R of 2.570. This means that EOL has a significant positive effect on CP. This finding supports Garver (1996) that there is a significant positive relationship between the size of learning activities and performance. According to Jashapara (1993) that learning in an organization has a positive impact on organizational performance. Similarly, Skerlavaj, Stemberger, Skrinjar and Dimovski (2006) that organizational learning has a positive direct impact on performance. The findings of Spicer and Sadler-Smith (2006) in small manufacturing companies also show that organizational learning has a positive relationship with the company's financial and non-financial performance. Similarly, many other empirical studies show a positive relationship between organizational learning and performance outcomes (Pudjiarti \& Hutomo, 2020; Correa, Morales, and Pozo (2007) Ellinger et al., 2003; Jimenez and Navarro (2006) Khandekar and Sharma (2006) Power and Waddell (2004) Schroeder, Bates, and Junttila, 2002). Test results of the moderating effect on effective organizational learning on human resource development and market uncertainty for company performance are shown in Table 2 . The results of the study showed that HRD had a significantly positive effect on $\mathrm{CP}$ with a value of $\mathrm{p}=0.016<$ from the value of $\alpha=0.05$. Likewise, market 
uncertainty has a positive effect on $\mathrm{CP}$ with a value of $\mathrm{p}=0.023<$ than $\alpha=0.05$. so the hypothesis is accepted. Thus, it can be proven that the effective organizational learning moderates HRD and market uncertainty to improve company performance, with a coefficient of 0.095 and a value of $p=0.010<$ from the value of $\alpha=0.05$.

\section{Conclusion}

This study examined empirically the variables of human resource development and market uncertainty moderated by the effective organizational learning to increase corporate performance. The results prove that effective organizational learning moderates human resource development and market uncertainty in their activities. These results prove that human resource development is needed to improve the effective organizational learning. Likewise, market uncertainty is a challenge to adjust to consumer preferences that change rapidly, in addition to the growing need and wider desire. Individual improvement efforts can increase corporate performance, because companies are required to maintain their best employees. Likewise, the pressure of new product offerings when market conditions fluctuate, the company is able to adjust to the demands of product needs or new product innovations. Thus, the effective organizational learning will have more value that is able to maintain the growth and performance of the company. A very interesting thing is that if the market fluctuates rapidly and the company does not quickly learn quickly it will have a negative effect on company performance. Empirically effective organizational learning has a moderating positive relationship between human resource development and market uncertainty to increase corporate performance. Furthermore, in organizational learning that needs attention is whether the rapidly volatile market is still able to be controlled or anticipated quickly by the company. Because rapid market changes must be responded to with changes in the capability of human resources to quickly adjust to the competencies they have. Thus, the HRM Corporation became very big for the success of the company.

\section{References}

Afuah, A. (1998) Innovation Management: Strategies, Implementation and Profits. New York: Oxford University Press. Alagaraja, M. (2013). HRD and HRM Perspectives on Organizational Performance: a review of literature. Human Resource Development Review 12, 117-143.

Alagaraja, M. (2014). A Conceptual Model of Organizations as Learning-Performance Systems: Integrative Review of Lean Implementation Literature. Human Resource Development Review, 13(2), 207-233.

Alagaraja, M., Cumberland, D.M. and Choi, N. (2015). The mediating role of leadership and people management practices on HRD and organizational performance. Human Resource Development International 18, 220-234.

Argyris, C. and Schön, D.A. (1996). Organizational Learning II: Theory, Method, and Practice, Massachusetts: AddisonWesley.

Cameron, K. (1980). Critical questions in assessing organizational effectiveness. Organizational dynamics 4, 66-80.

Chen, N. (2008). Internal/Employee communication and organizational effectiveness: a study of Chinese corporations in transition. Journal of Contemporary China 17,167-189.

Choe, J. M. (2004). The relationships among management accounting information, organizational learning and production performance. Journal of Strategic Information Systems 13, 61-85.

Chonko, L.B., Dubinsky, A.J., Jones, E. and Roberts, J.A. (2003). Organizational and individual learning in the sales force: an agenda for sales research. Journal of Business Research. 56(12), 935-946.

Colbert, A. E., Barrick, M. R., \& Bradley, B. H. (2014). Personality and leadership composition in top management teams: Implications for organizational effectiveness. Personnel Psychology, 67(2), 351-387.

Connolly, T., Conlon, E. J., and Deutsch, S. J, (1980). Organizational effectiveness: a multiple-constituency approach. Academy of Management Review 5, 211-217.

Cooper, R. G., \& Kleinschmidt, E. J. (1995). Benchmarking the firm's critical success factors in new product development. Journal of Product Innovation Management: An International Publication of the Product Development \& Management Association, 12(5), 374-391.

Correa, F.A.A., Morales, V.J.G. and Pozo, E.C. (2007). Leadership and organizational learning's role on innovation and performance: lessons from Spain. Industrial Marketing Management, 36, 349-359.

Crossan, M.M., Lane, H.W., White, R.E. and Djurfeldt, L. (1995). Organizational learning: Dimensions for a theory. International Journal of Organizational Analysis 3(4), 337-360.

Dewar, R. D., \& Dutton, J. E. (1986). The adoption of radical and incremental innovations: An empirical analysis. Management Science, 32(11), 1422-1433.

Dodgson, M. (1991). Technology Learning, Technology Strategy and Competitive Pressures. British Journal of Management, 2(3), 132-149.

Dosi, G. (1988). The Nature of the Innovation Process. In G. Dosi, C. Freeman, R. Nelson, G. Silverberg, \& L. Soete (Eds.), Technical Change and Economic Theory (pp. 221-238). London: Pinter.

Easterby-Smith, M. (1997). Disciplines of organizational learning: Contributions and critiques. Human Relations,50(9), 1085-1113.

Ellinger, A.D., Elinger, A.E., Yang, B. and Howton, S.W. (2003). Making the business case for the learning organization concept: the problem and the solution. Advances in Developing Human Resources 5(2), 163-172.

Etzioni, A. (1960). Two approaches to organizational analysis: a critique and a suggestion. Administrative Science Quarterly $5,257-278$. 
Farjoun, M. (2010). Beyond dualism: Stability and change as a duality. Academy of Management Review, 35(2), $202-225$.

Garcia, R., \& Calantone, R. (2002). A critical look at technological innovation typology and innovativeness terminology: A literature review. Journal of Product Innovation Management 19(2), 110-132.

Garver, C.R. (1996). Organizational learning climate, self-directed learner characteristics, and job performance among the police officers. Unpublished doctorial dissertation. The Pennsylvania State University.

Garvin, D. A. (1993). Building a learning organization. Harvard Business Review 71(4), 78-91

Georgopoulos, B.S., \& Tannenbaum, A.S. (1957). A study of organizational effectiveness. American Sociological Review 22(5), 534-540.

Gioia, D. A., \& Chittipeddi, K. (1991). Sensemaking and sensegiving in strategic change initiation. Strategic management journal, 12(6), 433-448.

Gonzales, J.J. (2001). Merging organizational learning with learning theory - a task for the 21 st Century. Journal of Structural Learning \& Inteligence System, 14, 355-369.

Goodman, P.S, \& Pennings, J.M. (1977). Perspectives and Issues: An Introduction. In Goodman, P.S., Pennings, J.M. \& Associates (Ed) New Perspectives Organizational Effectiveness, San Francisco: Jossey Bass.

Griliches, Z., \& Lichtenberg, F. R. (1984). R\&D and productivity growth at the industry level: is there still a relationship?. In $R \& D$, patents, and productivity (pp. 465-502). University of Chicago Press.

Gulati, R. (1999) Network location and learning: The influence of network resources and firm capabilities on alliance formation. Strategic Management Journal 20(5), 397-420.

He, Z. L., \& Wong, P. K. (2004). Exploration vs. exploitation: An empirical test of the ambidexterity hypothesis. Organization science, 15(4), 481-494.

Henderson, R., \& I. Cockburn. (1996). Scale, Scope and Spillovers: The Determinants of Research Productivity in Drug Discovery. Rand Journal of Economics 27(1), 32- 59.

Hendry, C. (1996). Understanding and creating while organizational change through learning theory. Human Relations 49(5), 621-641.

Huang, L., \& Chen, A. (2010, August). Pre-Training Motivation and Transfer of Training in Downsizing Environments: A Preliminary Review and Perspectives. In 2010 International Conference on Management and Service Science (pp. 1-4). IEEE.

Hult, G. T. M., Hurley, R. F., \& Knight, G.A. (2004). Innovativeness: Its antecedents and impact on business performance. Industrial Marketing Management 33, 429-438.

Hutomo, P. T. P., \& Pudjiarti, E. S. (2018). Corporate Governance and HRM Practice on Consumption Product Sector Listed in Indonesia Stock Exchange. European Research Studies Journal, 21(3), 132-142.

Jashapara, A. (1993). The competitive learning organization: a quest for the holly grail. Management Decision 31(8), 5262.

Jaworski, B. J., \& Kohli, A. K. (1993). Market orientation: antecedents and consequences. Journal of marketing, 57(3), 5370.

Jiang, J.Y., \& Liu, C.W. (2015). High performance work systems and organizational effectiveness: The mediating role of social capital. Human Resource Management Review 25 (1), 126-137.

Jimenez, D.J. \& Navarro, J.G.C. (2006). The performance effect of organizational learning and market orientation. Industrial Marketing Management 36(6), 694-708.

Kareem, M. A. (2019). The Impact of Human Resource Development on Organizational Effectiveness: An Empirical Study. Management Dynamics in the Knowledge Economy, 7(1), 29-50.

Katz, D., \& Kahn, R. L. (1978). The social psychology of organizations. New York: Wiley.

Keats, B. W., \& Hitt, M. A. (1988). A causal model of linkages among environmental dimensions, macro organizational characteristics, and performance. Academy of Management Journal, 31(3), 570-598.

Khandekar, A., \& Sharma, A. (2006). Organizational learning and performance: understanding Indian scenario in present global context. Education and Training 48 (8/9), 682-692.

Kipley, D., Helm-Stevens, R., \& Lookinbee-Kipley, M. (2018). The Impact Of Environmental Turbulence On Organizational Learning. Archives of Business Research, 6(3).

Lee, C. H., \& Bruvold, N. T. (2003). Creating value for employees: investment in employee development. The International Journal of Human Resource Management, 14(6), 981-1000.

Lopez, S.P., Peon, J.M.M., \& Ordas, C.J.V. (2005). Organizational learning as a determining factor in business performance. The Learning Organization 12(3), 227-245.

Madhavan, R., \& Grover, R. 1998. From embedded knowledge to embodied knowledge: New product development as knowledge management. Journal of Marketing 62(4), 1-12.

March, J. G. (1991). Exploration and exploitation in organizational learning. Organization science, 2(1), 71-87.

Marsick, V., \& Watkins, K. (1994). The learning organization: An integrative vision for HRD. Human Resource Quarterly, 5, 353-360

Meyers, P. W., \& Tucker, F. G. (1989). Defining roles for logistics during routine and radical technological innovation. Journal of the Academy of Marketing Science, 17(1), 73-82.

Miles, R. E., Snow, C. C., Meyer, A. D., \& Coleman Jr, H. J. (1978). Organizational strategy, structure, and process. Academy of management review, 3(3), 546-562. 
Milliken, F. J. (1987). Three Types of Perceived Uncertainty about the Environment: State, Effect and Response Uncertainty. Academy of Management Review 12(1), 133-143.

Mufti, M. Y., Pudjiarti, E. S., \& Susetyo, D. (2019). Analysis of Second Order Person-Environment Fit on Innovative Work Behavior and Individual Performance. Arthatama, 3(2), 100-113.

Nilsson, S., \& Ellstrom, P. E. (2012). Employability and talent management: challenges for HRD practices. European Journal of Training and Development 36, 26-45.

OECD. (2005). Oslo Manual: Guidelines for Collecting and Interpreting Innovation Data (3rd ed.). Paris: Joint Publication of the OECD and the Statistical Office of the European Communities.

Otoo, F.N., \& Mishra, M. (2018). Measuring the impact of human resource development (HRD) practices on employee performance in small and medium scale enterprises. European Journal of Training and Development, 42(7/8), 517-534, doi: 10.1108/EJTD-07-2017-0061

Papadimitriou, D., \& Taylor, R. (2000). Organizational effectiveness of Hellenic national sports organizations: A multiple constituency approach. Sport Management Review 3, 23-46.

Pavitt, K. (1991). Key Characteristics of the Large Innovating Firm. British Journal of Management 2, 41-50.

Pfeffer, J. (1977). Usefulness of the concept. In P. S. Goodman \& J. M. Pennings (Eds.), new perspectives on organizational effectiveness. (pp. 132-143).

Power, J. \& Waddell, D. (2004). The link between self-managed work teams and learning organizations using performance indicators. The Learning Organization 11(2/3), 244-259.

Price, J. L. (1968). The study of organizational effectiveness. Sociological Quarterly 13, 3-15.

Probst, G., \& Raisch, S. (2005). Organizational crisis: The logic of failure. Academy of Management Perspectives, 19(1), 90-105.

Pudjiarti, E. S., \& Hutomo, P. T. P. (2020). The critical role of effective organizational learning to improve firm's innovation and performance in a market turbulence condition. International Journal of Innovation Science, 12(3), 237-254

Quinn, R. E., \& Rohrbaugh, J., (1981). A competing values approach to organizational effectiveness. Public Productivity Review 5, 122-140.

Raghuram, S. (1994). Linking staffing and training practices with business strategy: A theoretical perspective. Human Resource Development International, 5(3), 237-251.

Rahman, A.A., Imm Ng, S., Sambasivan, M., and Wang, F. (2013). Training and organizational effectiveness: moderating role of knowledge management process. European Journal of Training and Development 37, 472-488.

Rajesh K. Chandy and Gerard J. Tellis (1998); Organizing for Radical Product Innovation: The Overlooked Role of Willingness to Cannibalize Journal of Marketing Research 35(4), 474-487

Riordan, C.M., Vandenberg, R.J. \& Richardson, H.A. (2005). Employee involvement climate and organizational effectiveness. Human Resource Management $44,471-488$.

Roy, M, H., \& Dugal, S.S. (2005). Using employee gain sharing plans to improve organizational effectiveness. Benchmarking 12, 250-259.

Salomo, S., Talke, K., and Strecker, N. (2008). Innovation Field Orientation and Its Effect on Innovativeness and Firm Performance. Journal of Product Innovation Management 25: 560- 576.

Santos-Vijande, M.L., \& Álvarez-González, L.I. (2007). Innovativeness and Organizational Innovation in Total Quality Oriented Firms: The Moderating Role of Market Turbulence. Technovation, 27,514-532.

Schroeder, R.G., Bates, K.A., \& Junttila, M.A. (2002). A resource-based view of manufacturing strategy and the relationship to manufacturing performance. Strategic Management Journal 23, 105-117.

Shih, H. A., Chiang, Y. H., \& Hsu, C. C. (2006). Can high performance work systems really lead to better performance?. International journal of Manpower, 27(8), 741-763.

Slater, S.F., Narver, J.C. (1994). Does competitive environment moderate the market orientation-performance relationship? Journal of Marketing 58, 46-55.

Song, X. M., \& Montoya-Weiss, M. M. (1998). Critical development activities for really new versus incremental products. Journal of Product Innovation Management: An International Publication Of The Product Development \& Management Association, 15(2), 124-135.

Sowa, J. E., Selden, S. C., \& Sandfort, J. R. (2004). No longer immeasurable?. A multidimensional integrated model of nonprofit organizational effectiveness. Nonprofit and Voluntary Sector Quarterly 33, 711-728.

Spicer, D. P., \& Sadler-Smith, E. (2006). Organizational learning in smaller manufacturing firms. International Small Business Journal, 24(2), 133-158.

Stemberger, M.I., Skrinjar, R., \& Dimovski, V. (2006). Organizational learning culture- the missing link between business process change and organizational performance. International Journal Production Economics 106, 346-367.

Stiles, P., \& Kulvisaechana, S. (2003). Human capital and performance: A literature review. University of Cambridge: Cambridge.

Subramaniam, M., \& Youndt, M.A. (2005) The Influence of Intellectual Capital on the Types of Innovative Capabilities. Academy of Management Journal, 48, 450-463.

Sun, H.-C. (2003). Conceptual clarifications for "organizational learning," "learning organization," and "a learning organization." Human Resource Development International, 6(2), 153-166.

Sutcliffe, K. M., \& Zaheer, A. (1998). Uncertainty in the transaction environment: an empirical test. Strategic management journal, 19(1), 1-23. 
Trieschmann, J. S., Dennis, A. R., Northcraft, G. B., \& Niemi, A. W., Jr. (2000). Serving multiple constituencies in the business school: M.B.A. program versus research performance. Academy of Management Journal 43, 130-141.

Tsang, E.W.K. (1997). Organizational learning and the learning organization: A dichotomy between descriptive and prescriptive research. Human Relations 50(1): 73-89.

Wang, Y. L., \& Huang, S. (2013). Organizational learning and human resource: A review of the theory and literatures. International Proceedings of Economics Development and Research, 61, 56.

Weese, W. J. (1997). The development of an instrument to measure effectiveness in campus recreation programs. Journal of Sport Management 11(3), 263-274

Wolfe \& Putler, 2002 Wolfe, R.A., \& Putler, D.S. (2002). How tight are the ties that bind stakeholder groups? Organization Science 13, 64-80.

Wu, F., \& Cavusgil, S.T. (2006). Organizational learning and joint value creation in interfirm relationships. Journal of Business Research 59, 81-89.

Yuchtman, R. F., and Seashore, S, (1967). A system resource approach to organizational effectiveness. American Sociological Review 32, 891-903.

Zgrzywa-Ziemak, A. (2015). The impact of organisational learning on organisational performance. Journal of Management and Business Administration. Central Europe, 23(4), 98-112.

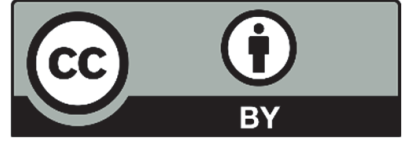

(C) 2021 by the authors; licensee Growing Science, Canada. This is an open access article distributed under the terms and conditions of the Creative Commons Attribution (CC-BY) license (http://creativecommons.org/licenses/by/4.0/). 